\section{A New Insecticidal Pyrethroid} Ester $^{11}$

Keimei Fujimoto, Nobushige ITaya, Yoshitoshi OKuno, Tadaomi Kadota and Takashi YAMAGUCHI

Research Department, Pesticides Division, Takarazuka Laboratory, Sumitomo Chem. Co, Ltd., 2-1, 4-chome, Takatsukasa Takarazuka, Hyogo

Received September 7, 1973

Since the structure of the insecticidal components of natural pyrethrin was elucidated by LaForge et al., ${ }^{2}$ many synthetic pyrethroids which are esters of chrysanthmic acid, have been discovered and industrially produced as insecticides of low mammalian toxicity for household use. Among these synthetic esters, the one with the most powerful knock-down activity is tetramethrin, ${ }^{3 !}$ and as for the killing effect, resmethrin is the most active. ${ }^{4}$ Furamethrin $^{5)}$ and proparthrin ${ }^{6)}$ are superior to allethrin in knock-down activity when used as an active ingredient of mosquito coil.

The present paper reports a new synthetic pyrethroid 'phenothrin' or 3-phenoxybenzyl chrysanthemate (I). The new chrysanthemate showed strong killing activity on various

TABle I. Refractive INDEX OF the Chrysanthemates

\begin{tabular}{lc}
\hline \multicolumn{1}{c}{ Material } & $\mathrm{N}_{3}^{35}$ \\
\hline Compound (I) (Phenothrin) & \\
dl-trans, cis & 1.5487 \\
d-trans & 1.5482 \\
d-cis & 1.5504 \\
l-trans & 1.5481 \\
l-cis & 1.5507 \\
Compound (II) & 1.5482 \\
Compound (III) & 1.5749 \\
\hline
\end{tabular}

Table II. Toxicity of the Chrysanthemates to Insects AND Mice

\begin{tabular}{|c|c|c|c|c|c|}
\hline \multirow{3}{*}{ Material $^{a .}$} & \multicolumn{5}{|c|}{ Toxicity } \\
\hline & \multicolumn{2}{|c|}{ House fly ${ }^{(1)}$} & \multirow{2}{*}{$\begin{array}{l}\text { Army wormet } \\
\text { Mortality } \\
\text { LC }_{50} \\
\text { (pprm) }\end{array}$} & \multirow{2}{*}{$\begin{array}{c}\text { Green pea } \\
\text { aphid }{ }^{0 !} \\
\text { Mortality } \\
\text { LC } C_{50} \\
(\text { ppm) }\end{array}$} & \multirow{2}{*}{$\begin{array}{c}\text { Mice }^{d,} \\
\text { Mortality, oral } \\
\text { LC } C_{50} \\
(\mathrm{mg} / \mathrm{kg})\end{array}$} \\
\hline & $\begin{array}{c}\text { Knock-down } \\
\text { KT }_{50}, \mathrm{sec} \\
(0.5 \%)\end{array}$ & $\begin{array}{c}\text { Mortality } \\
\text { LC } C_{50} \\
(\mathrm{mg} / 100 \mathrm{ml})\end{array}$ & & & \\
\hline \multicolumn{6}{|l|}{ Compound (I) (Phenothrin) } \\
\hline dl-trans, cis & 430 & 22.0 & 132 & 250 & $>5000$ \\
\hline$d$-trans, cis & 345 & 11.0 & 50 & 98 & $>5000$ \\
\hline d-trans & 390 & 11.8 & 58 & 100 & $>10,000$ \\
\hline$d$-cis & 258 & 15.5 & 43 & 85 & 480 \\
\hline l-trans & $>1000$ & $>1000$ & $>2000$ & $>2000$ & $>5000$ \\
\hline l-cis & $>1000$ & $>1000$ & $>2000$ & $>2000$ & - \\
\hline Compound (II) & $>1000$ & 46.5 & 333 & - & $>5000$ \\
\hline Compound (III) & $>1000$ & 110 & 980 & $一$ & $>1000$ \\
\hline Tetramethrin & 43 & 135 & $>2000$ & 700 & 1220 \\
\hline Pyrethrin & 50 & 120 & 250 & 193 & 130 \\
\hline Resmethrin & 180 & 8.2 & 71 & 150 & 300 \\
\hline Furamethrin & 127 & 58.4 & 500 & $>2000$ & 3130 \\
\hline$d$-Furamethrin ${ }^{b}$ & 62 & 31.3 & 260 & $>2000$ & 1950 \\
\hline Allethrin & 125 & 144 & $>1000$ & 980 & $410^{\epsilon 1}$ \\
\hline$d$-Allethrin ${ }^{b}$ & 56 & 68.3 & 483 & 500 & $440^{\circ}$ \\
\hline
\end{tabular}

a) The ratio of $d$-cis, $d$-trans, l-trans and l-cis isomers is $40: 10: 40: 10$.

b) The ratio of $d$-trans and $d$-cis isomers is $80: 20$.

c) Knock-down: Glass chamber method with oil-based space spray. Mortality of house fly: with Campbell's turn table method. Mortality of army worm and aphid: tested on insects released on the leaf sprayed with an emulsion.

d) Tested with $10 \%$ Tween- 80 suspension except. ${ }^{e}$

e) Tested with $1 \% \mathrm{CMC}$ suspension. 
TAble III. Stability Under Xenon Lamp Irradiation ${ }^{a}$,

\begin{tabular}{cccccc}
\hline \multirow{2}{*}{ Pyrethroid } & Irradiation & \multicolumn{4}{c}{ Residual rate of pyrethroids $^{b^{\prime}}$} \\
\cline { 3 - 6 } & & $11 \mathrm{hr}$ & $24 \mathrm{hr}$ & $72 \mathrm{hr}$ & $120 \mathrm{hr}$ \\
\hline Phenothrin & + & - & 87.7 & 50.6 & 18.9 \\
\multirow{3}{*}{ Resmethrin } & - & - & - & - & 98.7 \\
& + & 90.4 & 46.9 & 15.1 & 2.5 \\
& - & - & - & - & 99.1 \\
\hline
\end{tabular}

a) $6000 \sim 6300$ lux, $38 \sim 41^{\circ} \mathrm{C}$.

b) Initial value: Phenothrin, $285 \mathrm{mg} / 38.5 \mathrm{~cm}^{2}=100$

Resmethrin, $287.5 \mathrm{mg} / 38.5 \mathrm{~cm}^{2}=100$

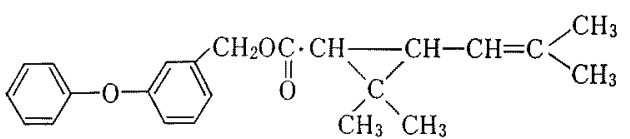<smiles>CC(C)=CC1C(C(=O)OCc2cccc(Cc3ccccc3)c2)C1(C)C</smiles><smiles>CC(C)=CC1C(C(=O)Cc2cccc(Sc3ccccc3)c2)C1(C)C</smiles>

species of insects, is least toxic to mice and physicochemically most stable relative to the known pyrethroids.

The compound (I) was prepared by esterifying 3-phenoxybenzyl alcohol with chrysanthemoyl chloride and pyridine. 3-Phenoxybenzyl alcohol was readily synthesized from 3-phenoxy-toluene by either halogenation followed by hydrolysis or oxidation with gaseous oxygen. The compound was colorless liquid and refractive indexes of each isomers are shown in Table $\mathrm{I}$.

As seen from Table II, the killing activities of phenothrin were superior to those of other pyrethroids except resmethrin as compared with the related compounds (II), ${ }^{7 /}$ (III) ${ }^{8)}$ and the representative synthetic pyrethroids. Phenothrin was less active in knock-down effect than the others. Only the esters of $d$-cis and $d$-trans chrysanthemic acid were insecticidally active. Phenothrin was found to be more resistant than resmethrin on irradiation with ultraviolet light (see Table III).

Beacause of the outstanding killing activity, the remarkable low toxicity to mammals and good stability to ultraviolet light, phenothrin appears to be one of the most promising insecticides for both sanitary and agricultural purposes. Experimental details will be published elsewhere in the near future.

The authors are grateful to Sumitomo Chemical Co., Ltd. for permission to publish these results.

\section{REFERENCES}

1) K. Fujimoto, Y. Okuno, N. Itaya, K. Kamoshita, T. Mizutani, S. Kitamura, S. Nakai and N. Kameda, Japan Patent 21473 (published June 17, 1971).

2) F. B. LaForge and H. L. Haller, J. Amer. Chem. Soc., 58, 1777 (1936).

3) T. Kato, K. Ueda and K. Fujimoto, Agr. Biol. Chem., 28, 914 (1965).

4) M. Elliott, A. W. Farnham, P. H. Needham and B. C. Pearson, Nature, 213, 493 (1967).

5) Y. Katsuda, T. Chikamoto, H. Ogami, H. Hirobe and T. Kunishige, Agr. Biol. Chem., 33, 1361 (1969).

6) M. Nakanishi, T. Mukai, S. Inamasu, A. Tsuda and T. Abe, Botyu-Kagaku, 35 (1970).

7) K. Fujimoto, Y. Okuno, N. Itaya, S. Kitamura, T. Mizutani and K. Kameda, Japan Patent 26359 (published July 30, 1971).

8) K. Fujimoto, Y. Okuno, N. Itaya, K. Kanoshita, T. Mizutani, S. Kitamura, S. Nakai and N. Kameda, Japan Patent 21474 (published June 17, 1971). 